\title{
Antifungal activity of Syzygium cumini L. against Rhizoctonia solani
}

\author{
Afshan Khan, Khajista Jabeen* and Sumera Iqbal \\ Department of Botany, Lahore College for Women University, Lahore, Pakistan \\ *Corresponding author's email: khajista_1@ hotmail.com \\ Citation \\ Afshan Khan, Khajista Jabeen and Sumera Iqbal. Antifungal activity of Syzygium cumini L. against Rhizoctonia \\ solani. Pure and Applied Biology. Vol. 5, Issue 2, 2016, pp193-199. http://dx.doi.org/10.19045/bspab.2016.50025
}

\begin{tabular}{llll}
\hline \hline Received: 07/12/2015 & Revised: 08/02/2016 & Accepted: 12/02/2016 & Online First: 16/02/2016 \\
\hline
\end{tabular}

\section{Abstract}

Antifungal activity of Syzygium cumini (L.) Skeels bark and leaves were evaluated against Rhizoctonia solani Kuhn, the causal agent of damping-off. Extracts of bark and leaves of $S$. cumini were prepared in methanol at a concentrations viz. $1 \%, 2 \%, 3 \%, 4 \%$ and $5 \%$ were tested against the target pathogen. Methanolic bark extract of $S$. cumini was found more effective and showed high antifungal potential as compared to leaf extract. The methanolic bark extract was subjected to bioassay guided fractionation and different organic fractions like ethyl acetate, chloroform, $n$-hexane and $n$-butanol were isolated. The isolated fractions were further serially diluted to check their Minimum Inhibitory Concentration along with a synthetic fungicide Puslan (72\% WP). The MIC of various concentrations from (1.56-200 $\mathrm{mg} \mathrm{mL}^{-1}$ ) was recorded for each fraction at the intervals of 24,48 and 72 hours. $n$-butanol and Puslan were highly effective in inhibiting the mycelium growth of $R$. solani with MIC of $1.56 \mathrm{mg} / \mathrm{ml}$.

Key words: Antifungal activity; Damping off; Jaman; MIC; Plant extract

\section{Introduction}

Rhizoctonia solani Kuhn is a soil born fungal pathogen that causes damping off disease in members of different plant families such as Leguminosae, Graminae, Solanaceae, Brassicaceae, Cucurbitaceae, Malvaceae, Chenopodiaceae, Cyperaceae and Caryophyllaceae [1, 2]. The pathogen inhabits in the soil as thick walled sclerotia and brown colour hyphae. Due to heavy yield losses in economical important crops by $R$. solani have been reported worldwide $[3,4]$.

Since, the pathogen causes large economic losses therefore, a number of management techniques have been developed. Cultural practices such as soil mulching, planting date adjustment, deep ploughing, irrigation timing and crop rotation can help to control the disease [5]. But these practices are not effective enough to control the disease. Resistant varieties can also be used in disease control but it has been found that genetic resistance cannot be much effective measure [6]. Although fungicides help to reduce this fungal disease, but the chemical residues of fungicides can persist inside plant tissue and such residues persisting in fruit or vegetables may cause hazardous effects on consumers health [7-10] .

The problems raised by using synthetic pesticides increased the need of alternative biodegradable pesticides [11]. The plant world can provide nontoxic and biodegradable natural products which can be effective in controlling many phytopathogens. These bioactive natural compounds are secondary metabolites 
including terpenoids, quinines and tannins [12].

Syzygium cumini (L.) Skeels is an evergreen tree belongs to family Myrtaceae native to sub-continent region. S. cumini is rich in compounds containing anthocyanins, acylated flavonol glycosides, glucosides, ellagic acid, isoquercetin, kaemferol and myrecetin, myricetin, 3-O-4-acetyl-Lrhamnopyranoside, quercetin, triterpenoids, esterase, galloyl carboxylase, tanninsbetulinic acid, friedelin, epifriedelanol, beta-sitosterol, eugenin and fatty acid ester of epi-friedelanol [13-15]. So, the present study is designed to evaluate the antifungal activity of $S$. cumini against $R$. solani.

\section{Materials and methods}

The present study was conducted at Plant Pathology Lab at Botany Department, Lahore College for Women University, Lahore, Pakistan, in 2013. Leaves and bark of $S$. cumini were collected from the Government Employees Co-operative Housing Society Town Ship, Lahore (Longitude: $74^{\circ} 20^{\prime} 36^{\prime} \mathrm{E}$, Altitude: $688 \mathrm{ft}$ ). The plant material was dried under sunlight and stored in polythene bags. Culture of test fungus $R$. solani was prepared by sprinkling contaminated soil on PDA medium. This culture was sub-cultured and maintained on 2\% PDA (Potato Dextrose Agar) and stored in refrigerator at $4^{\circ} \mathrm{C}$ for future use.

\section{Antifungal bioassays}

Twenty grams of dried material of each plant part of $S$. cumini was soaked in $100 \mathrm{ml}$ methanol and left for three days at room temperature. After three days the soaked material was filtered through an autoclaved muslin cloth. This methanolic extract was evaporated to reduce their volume up to $2 \mathrm{ml}$ under dried oven at $35^{\circ} \mathrm{C}$ and then diluted by adding appropriate amount of distilled water to make the final volume of $100 \mathrm{ml}$. The stock solvent extracts thus, made were stored in refrigerator at $4^{\circ} \mathrm{C}$ and used within four days.

Potato Dextrose Agar (2\%) was prepared by adding $2 \mathrm{~g}$ PDA in $100 \mathrm{ml}$ distilled water in $250 \mathrm{ml}$ conical flask and this solution was autoclaved at $121^{\circ} \mathrm{C}$ for 30 minutes. Different concentrations 1, 2, 3, 4 and 5\% were prepared for experimental treatment. To make $1 \% \mathrm{w} / \mathrm{v}$ concentration $2 \mathrm{~g}$ of PDA was added in $95 \mathrm{ml}$ distilled water, to this solution $5 \mathrm{ml}$ of stock solution was added. Similarly, the remaining concentrations (that are 2, 3, 4 and 5\%) were prepared by adding $10 \mathrm{ml}, 15 \mathrm{ml}, 20 \mathrm{ml}$ and $25 \mathrm{ml}$ of stock solution respectively. Each concentration was supplemented with Chloromycetin capsule @ $50 \mathrm{mg} / 100 \mathrm{ml}$ to avoid bacterial contamination.

In vitro antifungal bioassay was conducted with the organic solvent extract. Three replicates of each applied concentration were prepared by pouring media into sterilized plates. Mycelial discs of $5 \mathrm{~mm}$ was prepared by using a cork borer from the pure culture of $R$. solani and placed in the center of each petri plate after solidification of PDA medium. These plates were incubated for 7 days at $25 \pm 2{ }^{\circ} \mathrm{C}$. After 7 days fungal growth diameter was measured by taking average of three diameters taken at right angles for each colony. Percentage growth inhibition of the fungal colonies was measured by using the formula:

Growth inhibition $(\%)=$ Growth intreatment - Growth in control x 100

\section{Growth in control}

\section{Bioassay guided fractionation}

Bark extract of $S$. cumini found more effective in screening bioassay so, the methanolic bark extract of $S$. cumini was partitioned with $n$-hexane, chloroform followed by ethyl acetate and $n$-butanol at room temperature. $300 \mathrm{~g}$ dried bark of $S$. cumini was fully extracted with $500 \mathrm{~mL}$ methanol at room temperature. The obtained extract was evaporated under vacuum on rotary evaporator (Buchi Switzzerland R- 
210) at $40^{\circ} \mathrm{C}$, this gave up turbid methanolic extract. The methanolic extract was then partitioned by using separating funnel between $n$-hexane and water. The obtained aqueous fraction was then partitioned successively with chloroform, ethyl acetate and $n$-butanol [16] according to increasing order of polarity. This partitioning yielded $2.2 \mathrm{~g} n$-hexane fraction, $2.1 \mathrm{~g}$ chloroform fraction, $0.2 \mathrm{~g}$ ethyl acetate fraction, $1.45 \mathrm{~g}$ $n$-butanol fraction and the remaining was water fraction.

The MIC values of the isolated fractions and synthetic fungicide Puslan 72 WP (Metalaxyl+Mancozeb) were determined in test tubes by serial dilution micro assay [17]. The four isolated fractions and synthetic fungicide were dissolved in DMSO (Dimethyl Sulfoxide). Maximum 200 mg/ $\mathrm{ml}$ concentration was prepared by adding 1 $\mathrm{ml}$ of DMSO and $1 \mathrm{ml}$ of distilled water, this concentration was further serially diluted and the minimum applied concentration was $1.56 \mathrm{mg} / \mathrm{ml}$. Freshly prepared malt extract medium was added to seven days old fungal culture of $R$. solani and $1 \times 10^{5} 100 \mu \mathrm{l}$ mycelial suspension was prepared and added in each concentration of all the four fractions, fungicide and control set. All the test tubes were incubated at $25-30^{\circ} \mathrm{C}$. The MIC of the fractions was observed after 24, 48 and 72 hours with the help of inverted microscope and the fungal mycelia growths were measured. .

The data was statistically analyzed by applying ANOVA followed by Duncan's Multiple Range Test at significant level $\mathrm{P} \leq 0.05$ by using co-stat software [18].

\section{Results and discussion}

In the present study the methanolic extract bark and leaf extract of S. cumini were evaluated for their antifungal potential against $R$. solani. All the applied concentrations of the methanolic bark extract of S. cumini (1- 5\%) significantly retarded the in vitro growth of the test fungus. However, concentration $5 \%$ was found to be highly effective and significantly surpassed all other treatments by reducing $43 \%$ of the fungal growth when compared to the control treatment. Followed by 3 and $4 \%$ which suppressed the colony diameter of $R$. solani by $35 \%$ and $40 \%$ respectively. Concentration $1 \%$ explored low significant effect and resulted in reduction of $25 \%$ of the fungal growth (Fig. $1 \& 2)$. Data regarding the methanolic extract of $S$. cumini leaves on in vitro growth of $R$. solani is presented in (Fig. $3 \& 4$ ). All the applied concentrations significantly retarded $R$. solani growth but the reduction amounts were less when compared to the observed bark antifungal activity. The maximum significant inhibition of the fungal growth observed at $5 \%$ concentration, which caused $28 \%$ reduction in the test fungal growth diameter when compared to control treatment. This concentration significantly surpassed all other treatment effects except $4 \%$ concentration. $1 \%$ concentration explored low significant effect and resulted in reduction of $25 \%$ of the fungal growth. Earlier Jabeen and Javaid [19] studied the antifungal potential of leaves, stem and root bark of S. cumini against Ascochyta rabiei. Aqueous, $n$-hexane and ethanol extracts of $S$. cumini significantly retarded the growth of the test fungus. Fifty two plants of different plant families were studied for their antifungal activity by Satish et al. [20]. Among all the tested plant aqueous extract of $S$. cumini alongwith Datura stramonium, Acacia nilotica, Lawsonia inermis, Peltophorum pterocarpum, Punica granatum, Eucalyptus globules, Polyalthia longifolia, Mimusops elengi, Prosopis juliflora and Peltophorum pterocarpum, showed strong antigungal activity against the tested Aspergillus species. Kuiate et al. [21] stated that antifungal activity $S$. jambosis due to the presence of friedeloactone and friedelintriterpenes. 
Results of the MIC of four isolated fractions in reference with the synthetic fungicide Puslan (Metalaxyl + Mancozeb, 72 WP) against $R$. solani growth revealed that $n$ butanol and synthetic fungicide were found most effective in inhibiting the mycelium production in $R$. solani even at lowest concentration of $1.56 \mathrm{mg}, 72 \mathrm{~h}$ of incubation period. Other fractions were found ineffective in inhibiting germination of the test fungus. The results of MIC determination are supported by the literature as Shihabudeen et al. [22] found that methanolic extract of Eugenia jambolana exhibited the highest antibacterial efficacy against Staphylococcus aureus and Pseudomonas aeruginosa at lower concentrations.

The present study concludes that different part of $S$. cumini contain antifungal constituents against the test fungus $R$. solani.

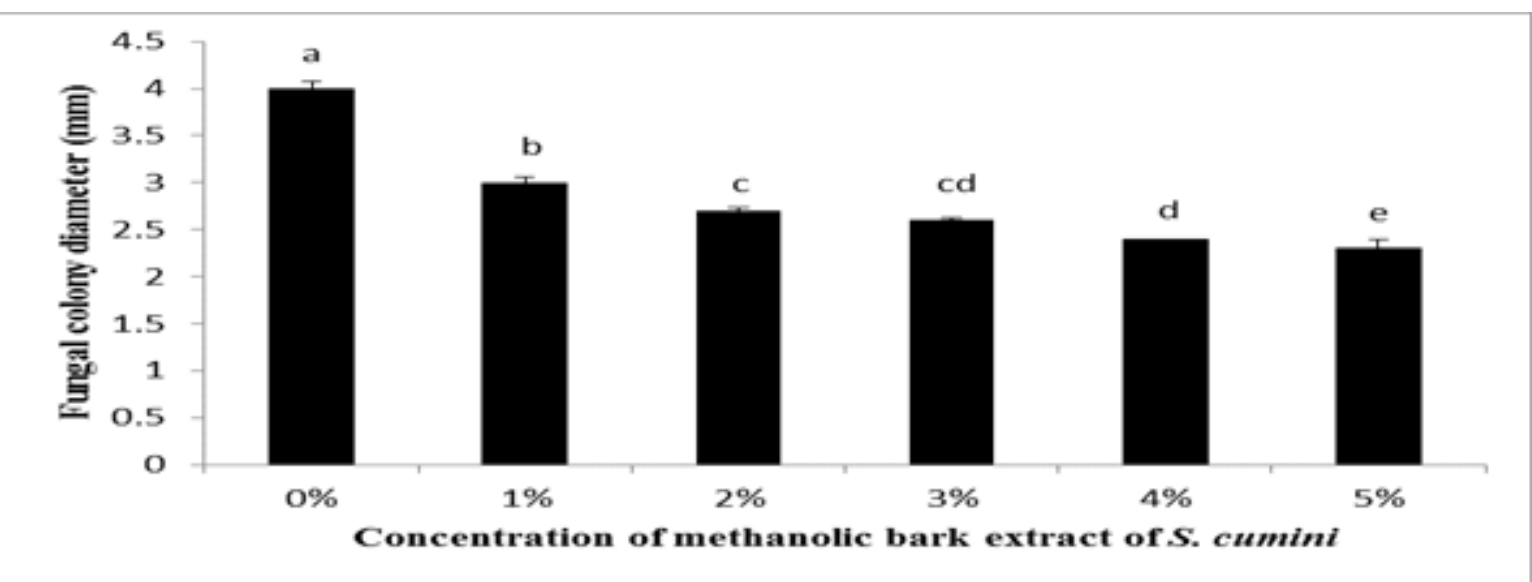

Figure 1. Antifungal activity of the methanolic bark extracts of S. cumini, on in vito growth of $R$ solani

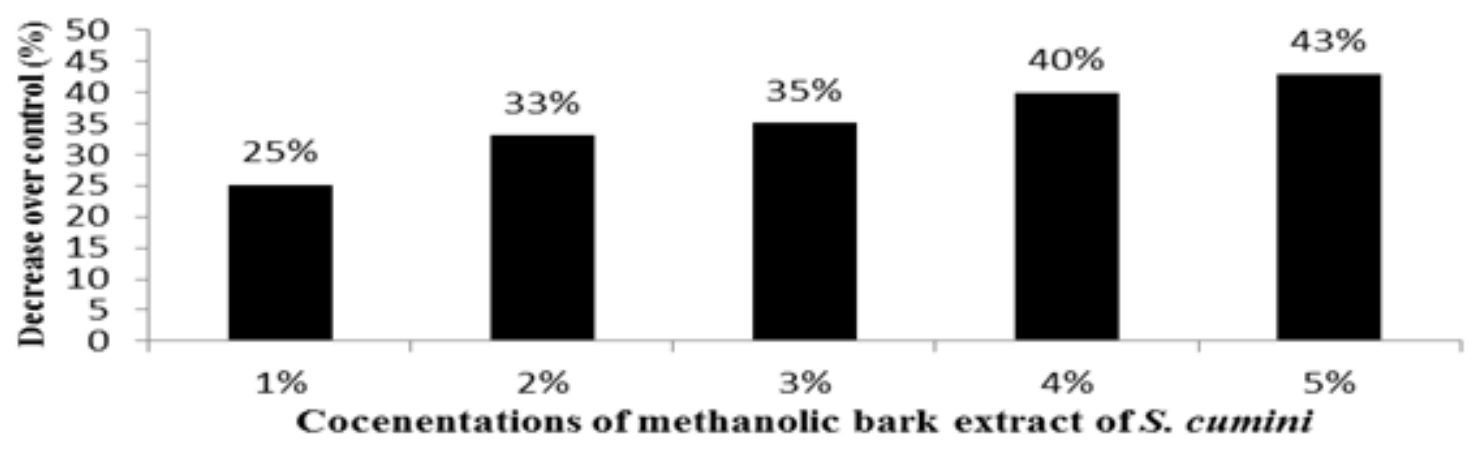

Figure 2. Percentage inhibition in diameter of $R$.solani due to different concentrations of methanolic bark extract of $S$. cumini. 


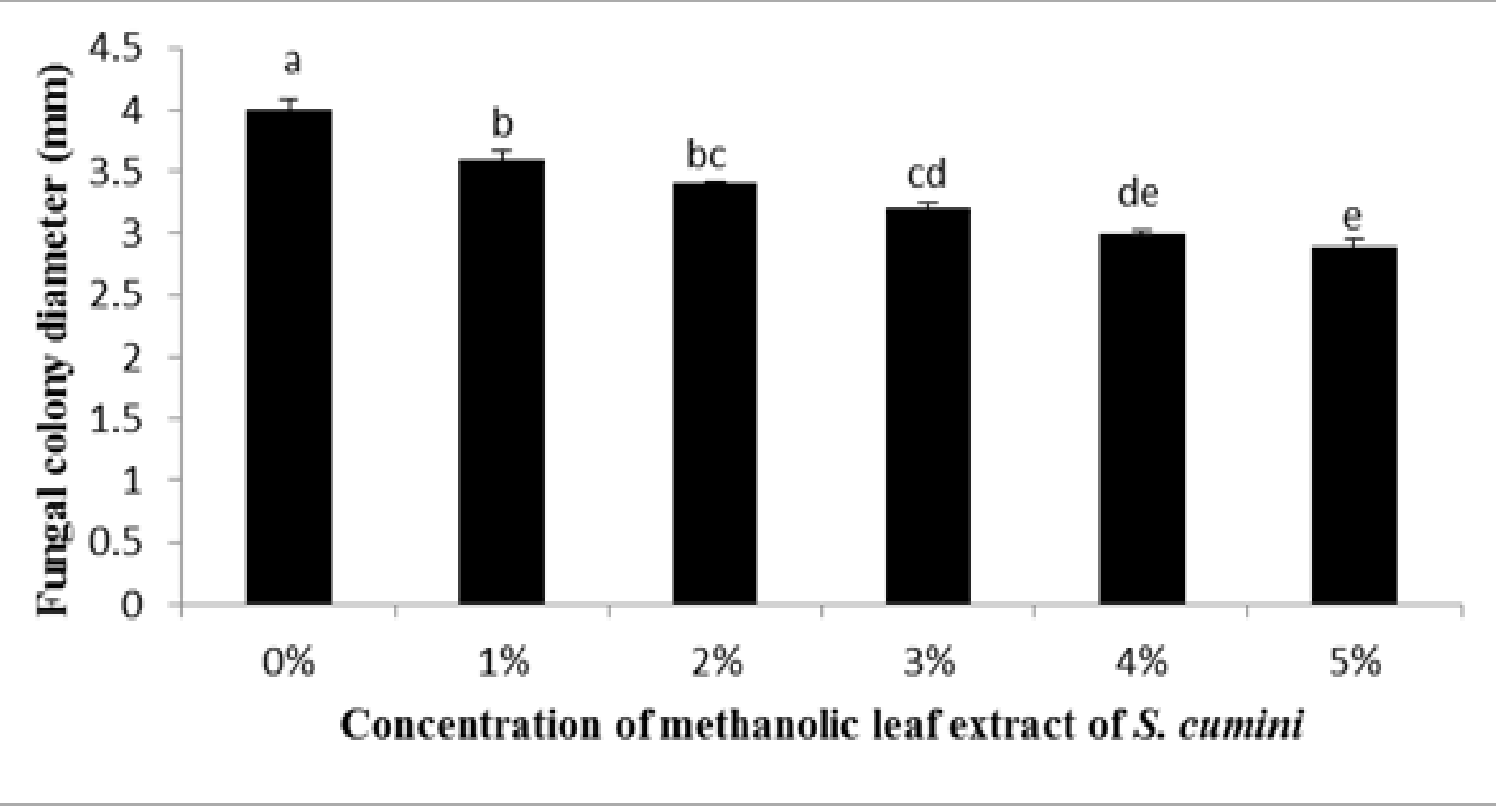

Figure 3. Antifungal activity of the methanolic leaf extracts of $S$. cumini, on in vitro growth of $R$ solani

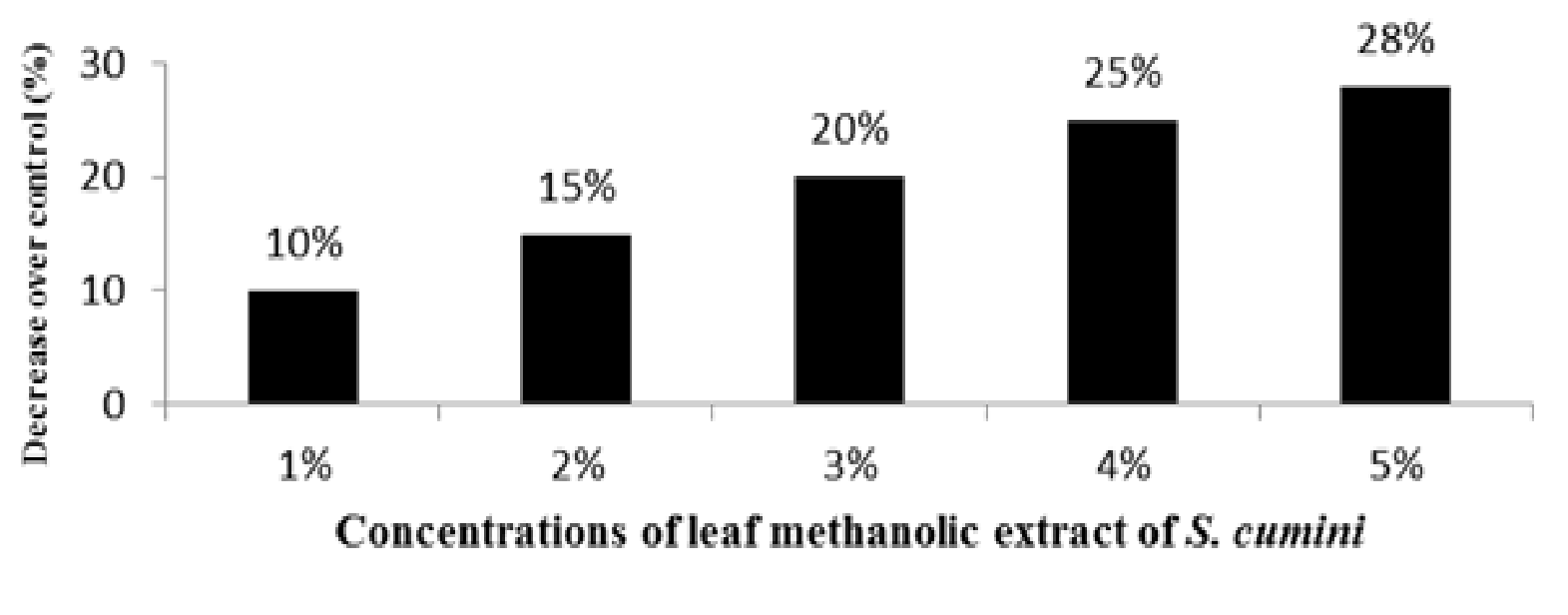

Figure 4. Percentage inhibition in diameter of $R$. solani due to different concentrations of methanolic leaf extract of $S$. cumini 
Table 1. MIC values of different organic fractions isolated from $\mathrm{S}$. cumini and the synthetic fungicide Puslan (Metalaxyl+Mancozeb, 72 WP) against $R$. solani, growth after 24, 48 and 72 h incubation period

\begin{tabular}{|c|c|c|c|c|c|c|c|c|}
\hline \multirow[t]{2}{*}{ Fractions } & \multicolumn{8}{|c|}{ Concentration ( $\mathrm{mg} / \mathrm{ml}$ ) } \\
\hline & $200 \mathrm{mg}$ & $100 \mathrm{mg}$ & $50 \mathrm{mg}$ & $25 \mathrm{mg}$ & $12.5 \mathrm{mg}$ & $6.25 \mathrm{mg}$ & $3.13 \mathrm{mg}$ & $1.56 \mathrm{mg}$ \\
\hline \multicolumn{9}{|c|}{24 hours after of incubation } \\
\hline Control $\left(\mathrm{H}_{2} \mathrm{O}\right)$ & + & + & - & + & + & + & + & - \\
\hline Control (DMSO) & - & + & - & + & - & - & + & - \\
\hline n-Hexane & - & - & - & - & + & + & + & + \\
\hline Chloroform & - & - & - & + & + & + & - & + \\
\hline Ethyl acetate & - & - & + & + & + & + & + & + \\
\hline n-Butanol & - & - & - & - & - & - & - & - \\
\hline Puslan 72\% WP & - & - & - & - & - & - & - & - \\
\hline \multicolumn{9}{|c|}{48 hours after incubation } \\
\hline Control $\left(\mathrm{H}_{2} \mathrm{O}\right)$ & + & + & + & + & + & + & + & + \\
\hline Control (DMSO) & + & + & + & + & + & + & + & - \\
\hline n-Hexane & - & - & - & + & + & + & + & + \\
\hline Chloroform & - & - & + & + & + & + & + & + \\
\hline Ethyl acetate & - & - & + & + & + & + & + & + \\
\hline n-Butanol & - & - & - & - & - & - & - & - \\
\hline Puslan 72\% WP & - & - & - & - & - & - & - & - \\
\hline \multicolumn{9}{|c|}{72 hours after incubation } \\
\hline Control $\left(\mathrm{H}_{2} \mathrm{O}\right)$ & + & + & + & + & + & + & + & + \\
\hline Control (DMSO) & + & + & + & + & + & + & + & - \\
\hline$n$-Hexane & + & + & + & + & + & + & + & + \\
\hline Chloroform & + & + & + & + & + & + & + & + \\
\hline Ethyl acetate & + & + & + & + & + & + & + & + \\
\hline n-Butanoln-Butanol & - & - & - & - & - & - & - & - \\
\hline Puslan 72\% WP & - & - & - & - & - & - & - & - \\
\hline
\end{tabular}

Mycelium present: (+), Mycelium absent: (-)

\section{Authors' contributions}

Conceived and designed the experiments: $\mathrm{K}$ Jabeen, Performed the experiments: A Khan, Analyzed the data: K Jabeen, A Khan \& S Iqbal, Contributed reagents/ materials/ analysis tools: K Jabeen \& S Iqbal, Wrote the paper: A Khan, K Jabeen \& S Iqbal.

\section{Reference}

1. Thornton RC, Groenh CA, Forrest R \& Lamotte R (2004). A one-step, immune chromatographic lateral flow device specific to Rhizoctonia solani and certain related species, and its use to detect and quantify $R$. solani in soil. Phytopathol 94: 280-288.

2. Naik MK \& Rani GSD (2008). Advances in soil borne plant diseases. New India
Publishing Agency. New Delhi, India. 89-127.

3. Wienhold AR, Bowman $\mathrm{T} \&$ Hall $\mathrm{DH}$ (1982). Rhizoctonia disease of potato: Effect on yield and control by seed tuber treatment. Plant Dis 66: 815-818.

4. Platt HW, Canale F \& Gimenez G (1993). Effects of tuber borne inoculums of Rhizoctonia solani and fungicidal seed potato treatment of plant growth and Rhizoctonia disease in Canada and Uruguay. Am Potato J 70: 553-559.

5. Hillocks RJ \& Waller JM (1997). Soilborne disease of tropical crops. Centre for Agricultural Bioscience International UK: 419. 
6. Mabrouk Y \& Belhadi O (2012). Integrated pest management in chickpea. New perspectives in plant protection. Bandani, AR. (Ed.). p. 1-31 (ISBN: 978953-51-0490-2).

7. Wightwick A \& Allinson G (2007). Pesticide residues in Victorian waterways: a review. Australas $J$ Ecotoxicol 13: 91-112.

8. Kibria G, Yousuf HAK, Nugegoda D \& Rose G (2010). Climate change and chemicals. Environmental and biological aspects. New India Publishing Agency, Pitam Pura, New Delhi. 460 p, ISBN $\backslash:$ 93-80235-30-1.

9. Komarek M, Cadkova E, Chrastny V, Bordas F \& Bollinger J C (2010). Contamination of vineyard soils with fungicides: A review of environmental and toxicological aspects. Environ Int 36: 138-151.

10. Martinez JA (2012). Natural fungicides obtained from plants. Fungicides for plant and animal diseases. Dr. Dharumadurai Dhanasekaran (Ed.). In Tech, ISBN: 978-953-307-804-5.

11. Al-Samarrai G, Singh H \& Syarhabil M 2012. Evaluating eco-friendly botanicals (natural plant extracts) as alternatives to synthetic fungicides. Ann Agr Env Med 19(4): 673-676.

12. Yazdani D, Tan YH, ZainalA bidin MA \& Jaganath IB (2011). A review on bioactive compounds isolated from plants against plant pathogenic fungi. $\mathrm{J} \mathrm{Med}$ Plants Res 5 (30): 6584-6589.

13. Timbola AK, Szpoganiez B, Branco A, Monache FD \& Pizzolatti M G (2002). A new flavonoid from leaves of Eugenia jambolana. Fitoterapia 73: 174-176.

14. Ayyanar M \& Subash-Babu P (2012). Syzygium cumini (L.) Skeels: A review of its phytochemical constituents and traditional uses. Asian Pac $J$ Trop Biomed 2(3): 240-246.

15. Mohamed AA, Ali SI \& El-Baz FK (2013). Antioxidant and antibacterial activities of crude extracts and essential oils of Syzygium cumini leaves. PLoS ONE 8(4): 60269.

16. Jabeen K, Javaid A, Ahmad E \& Athar M (2011). Antifungal Compounds from Meliaazedarach leaves for management of Ascochyta rabiei, the cause of chickpea blight. Nat Prod Res 25: 26476.

17. Jabeen K, Hanif $S$, Naz $S$ \& Iqbal $S$ (2013). Antifungal activity of Azadirachta indica against Alternaria solani. J Life Sci Technol 1: 89-92.

18. Steel RGD, Torrie JH \& Dickey DA (1997). Principles and procedures of statistics. A Biometrical Approach.McGraw Hill Book Co. Inc. (ISBN 0070610282) New York, USA.

19. Jabeen K \& Javaid A (2010). Antifungal activity of Syzygium cumini against Ascochyta rabiei - the cause of chickpea blight. Nat Prod Res 24(12): 1158-1167.

20. Satish S, Mohana D C, Ranhavendra M P \& Raveesha KA (2007). Antifungal activity of some plant extracts against important seed borne pathogens of Aspergillus sp. J Agric Technol 3(1): 109-119.

21. Kuiate JR, Mouokeu S, Wabo HK \& Tane P (2006). Antidermatophyte tictriterpenoids from Syzygium jambos (L.) Alston (Myrtaceae). Phytother Res 21: 149-152.

22. Shihabudeen HMS, Priscilla DH \& Thirumurugan K (2010). Antimicrobial activity and phytochemical analysis of selected Indian folk medicinal plants. Int J Pharma Sci Res 1(10): 430-434. 